\title{
MxA-Based Recognition of Viral Illness in Febrile Children by a Whole Blood Assay
}

\author{
MOTOKAZU NAKABAYASHI, YUICHI ADACHI, TOSHIKO ITAZAWA, YOSHIE OKABE, HIROKAZU KANEGANE, \\ MIZUHO KAWAMURA, AKIHITO TOMITA, AND TOSHIO MIYAWAKI \\ Department of Pediatrics [MN, YA, TI, YO, HK, TM], Faculty of Medicine, University of Toyama, Toyama 930-0194, Japan; Research \\ Laboratories [MK, AT], Kyowa Medex Co., Ltd., Shizuoka 411-0932, Japan
}

\begin{abstract}
Febrile children are often given antibiotics empirically and unnecessarily. MxA is a protein induced in peripheral lymphoid cells by type 1 interferons during active viral infection. The ability of a whole blood ELISA assay for MxA to identify children with viral illness was studied in 122 children who presented with acute onset fever and 52 age-matched healthy controls. The febrile children were divided into three groups according to their final diagnoses: etiologically diagnosed viral infection, clinically diagnosed viral infection, and bacterial infection. MxA levels in the bacterial infection group and controls were similar and low $(90.9 \pm 69.7$ and $76.9 \pm 63.2$ $\mathrm{ng} / \mathrm{mL}$, respectively). In contrast, mean MxA levels in the two viral infection groups were higher than in both the bacterial and control groups $(719.2 \pm 386.4$ and $827.0 \pm 651.1$, respectively). A receiver operating characteristic analysis showed that the area under the curve of the MxA level was greater than under the curves of both the white blood cell count and the C-reactive protein concentration. Whole blood assay of MxA is a clinically useful tool for diagnosing viral illness in febrile children and should help reduce use of unnecessary antibiotics. (Pediatr Res 60: 770-774, 2006)
\end{abstract}

$\mathrm{F}$ ever is one of the most frequent presentations among children seeking medical attention. It also is one of the most common symptoms of infectious disease. In developed countries, the etiology of most infectious diseases is viral (1). However, it is sometimes difficult to distinguish viral from bacterial infectious diseases in the clinical setting. Therefore, physicians often prescribe antibiotics to febrile patients empirically out of concern over the sequelae of bacterial infection. It has been reported that between $17 \%$ and $90 \%$ of children received antibiotics for the common cold, upper respiratory infections, and acute bronchitis, despite the fact that these illnesses are usually viral in origin (2). This inappropriate use of antibiotics is believed to be a main cause of the spread of antibiotic-resistant bacteria. The management of febrile infants is more complicated than the management of older children. These patients are at high risk for serious bacterial infections, such as meningitis and sepsis. Several criteria have been proposed for identifying patients with bacterial infection (3-5), but no man-

Received February 27, 2006; accepted July 16, 2006.

Correspondence: Yuichi Adachi, M.D., Ph.D., Department of Pediatrics, Faculty of Medicine, University of Toyama, 2630 Sugitani, Toyama 930-0194 Japan; e-mail: yadachi@

med.u-toyama.ac.jp

Supported by grants from the Ministry of Health, Laboratory and Welfare in Japan, and by Kyowa Medex Co., Ltd., Tokyo, Japan.

DOI: $10.1203 / 01 . p d r .0000246098 .65888 .5 b$ agement protocol has been universally adopted because reliable criteria for distinguishing between these two types of infection have yet to be developed.

Type I interferons (IFN- $\alpha$ and $-\beta$ ) play important roles in innate immune responses and have immunomodulatory, antiproliferative, and antiviral functions (6). Their antiviral activity is mediated by the induction of unique proteins, such as $2^{\prime}$, 5 '-oligoadenylate synthetase, RNAseL, dsRNA-activated protein kinase, and MxA (7). Human MxA is a 76-kDa GTPase protein belonging to the dynamic superfamily of large GTPase $(8,9)$ and has antiviral activity against a wide variety of viruses, such as influenza, parainfluenza, measles, and coxsackie viruses (10-13). MxA protein is induced exclusively by IFN- $\alpha$ and IFN- $\beta$, but not by IFN-gamma $(14,15)$. MxA protein may offer certain advantages as a marker for viral infection over the other induced proteins such as $2^{\prime}, 5^{\prime}$ oligoadenylate synthetase, because of its lower basal concentration and longer half-life (2.3 d) (16).

It has been reported that MxA expression in peripheral blood mononuclear cells (PBMC) is a highly specific and reliable marker for type I IFN bioactivity during IFN treatment of chronic viral hepatitis (17) and multiple sclerosis (18). We and other researchers have reported on the possible use of MxA protein expression in peripheral blood as a marker for viral infection (19-24). In this study, we show that MxA protein levels in peripheral whole blood are easily measured by an ELISA system, and that the whole blood MxA level is a good marker for distinguishing viral from bacterial disease in febrile children, even in infants less than 3 mo of age.

\section{MATERIALS AND METHODS}

Subjects. During the 18-mo period from October 2003 through March 2005, 122 children who visited the outpatient clinic of Toyama University Hospital for acute onset fever were enrolled in this study. Acute onset fever was defined as a body temperature higher than $38^{\circ} \mathrm{C}$ which developed within $1 \mathrm{wk}$ before presentation. Patients with immunodeficient diseases or chronic inflammatory diseases were excluded. Children with mild lower respiratory symptoms, such as wheezing, also were excluded to avoid infections by

Abbreviations: CRP, C-reactive protein; PBMC, peripheral blood mononuclear cells; ROC, receiver operating characteristic; WBC, white blood cell 
Table 1. Demographics of the study subjects

Acute onset of fever

\begin{tabular}{|c|c|c|c|c|}
\hline & \multicolumn{2}{|c|}{ Viral infection } & \multirow[b]{2}{*}{$\begin{array}{l}\text { Bacterial } \\
\text { infection }\end{array}$} & \multirow[b]{2}{*}{ Controls } \\
\hline & $\begin{array}{c}\text { Etiologically } \\
\text { diagnosed }\end{array}$ & $\begin{array}{l}\text { Clinically } \\
\text { diagnosed }\end{array}$ & & \\
\hline Number & 36 & 59 & 27 & 52 \\
\hline Age (year) & $2.8 \pm 3.8(0-14)$ & $1.3 \pm 1.9(0-9)$ & $1.8 \pm 3.7(0-14)$ & $3.8 \pm 4.1(0-12)$ \\
\hline Gender (male/female) & $16 / 20$ & $31 / 28$ & $15 / 12$ & $29 / 23$ \\
\hline Duration of fever (day) & $2.1 \pm 1.6$ & $1.5 \pm 1.8$ & $2.2 \pm 2.2$ & - \\
\hline
\end{tabular}

Values are expressed as mean \pm SD (range).

Table 2. Final diagnoses of the subjects with acute onset of fever

\begin{tabular}{|c|c|c|c|c|c|}
\hline \multicolumn{4}{|c|}{ Viral infection } & \multirow{2}{*}{\multicolumn{2}{|c|}{ Bacterial infection* }} \\
\hline \multicolumn{2}{|c|}{ Etiologically diagnosed } & \multicolumn{2}{|c|}{ Clinically diagnosed } & & \\
\hline Influenza virus $\mathrm{A} / \mathrm{B}$ & 13 & URI & 42 & UTI & 9 \\
\hline Adenovirus & 10 & Gastroenteritis & 10 & Pneumonia & 6 \\
\hline Rotavirus & 7 & Exanthema subitum & 5 & Sepsis & 4 \\
\hline RSV & 4 & Hand-foot-mouth disease & 1 & Tonsillitis & 2 \\
\hline Varicella & 1 & Croup syndrome & 1 & Retropharyngeal abscess & 1 \\
\hline \multirow[t]{5}{*}{ Cytomegalovirus } & 1 & & & Appendicitis & 1 \\
\hline & & & & Suppurative lymphadenitis & 1 \\
\hline & & & & Suppurative arthritis & 1 \\
\hline & & & & Salmonella enterocolitis & 1 \\
\hline & & & & Meningitis & 1 \\
\hline
\end{tabular}

Values are the number of the subjects.

RSV, respiratory syncytial virus; URI, upper respiratory infection; UTI, urinary tract infection.

Pathogens* (the number of the subjects).

UTI: Eschrichia coli (8), Enterococcus faecalis (1); pneumonia: Haemophilus influenzae (2), Streptococcus pneumoniae (1), Staphylococcus aureus (2), Serratia marcescens (1); sepsis: Staphylococcus aureus (3), Eschrichia coli (1); tonsillitis: Streptococcus pyogenes (1), Haemophilus influenza (1); retropharyngeal abscess: Haemophilus influenza (1); appendicitis: Eschrichia coli; suppurative lymphadenitis: Moraxella catarrhalis; suppurative arthritis: Staphylococcus aureus (1); Salmonella enterocolitis: Salmonella typhi (1); meningitis: Haemophilus influenza (1).

nonbacterial and nonviral pathogens such as Mycoplasma pneumoniae or Chlamydia pneumoniae, important causes of lower respiratory infection in wheezing children (25). Fifty-two age- and gender-matched healthy children who had been without symptoms of infectious diseases during the previous 2 wk served as controls (Table 1). The study was conducted according to the ethical standards of University of Toyama, which require informed consent from the parents of each subject.

Children with acute onset fever were subdivided into three groups according to the final diagnoses: etiologically diagnosed viral infection, clinically diagnosed viral infection, and bacterial infection (Table 2). Individuals with etiologically diagnosed viral infection were identified by elevated serum antibodies or positive results of virus-detection kits: ImmunoCard STAT! Adenovirus GSA (Meridian Bioscience, Cincinnati, OH) for adenovirus, ROTA-ADENO DRY (Orion Diagnostica, Espoo, Finland) for rotavirus, Capilia Flu A,B (Nippon Becton Dickinson, Tokyo, Japan) for influenza viruses, and Directigen RSV (Becton Dickinson, Cockeyville, M.D.) for respiratory syncytial virus. Children with mild symptoms of upper respiratory infection or gastroenteritis were classified into clinically diagnosed viral infection group. Their symptoms resolved spontaneously whether antibiotics were used or not. Some children with typical physical findings of viral infection, such as exanthem subitum, hand-foot-mouth disease or croup syndrome also were included in this group. Bacterial infections were diagnosed based on positive culture results. Samples for bacterial culture were obtained by collection bag, catheterization, or midstream collection of urine for urinary tract infection, sputum for pneumonia, venous blood for sepsis, throat swabs for tonsillitis, stool for enterocolitis, and aspiration specimens for other infections. According to Bachur's criteria using the results of urinalysis, white blood cell (WBC) count, body temperature, and age (26), infants aged younger than 3 mo were divided into one of two groups, "high risk" or "not high risk," for serious bacterial infection.

Measurement of MxA protein levels in peripheral whole blood by ELISA. The MxA protein level in whole blood sample, which had been stored at $-40^{\circ} \mathrm{C}$, was measured by an ELISA system according to a modification of the previously described method (27). Briefly, lysing solution was added to the thawed samples, and the lysate was applied to ELISA plates coated with a MAb (KM1135, Kyowa Medex, Tokyo, Japan). After $2 \mathrm{~h}$ of incubation, the plates were washed, and a different peroxidase-labeled MAb (KM1124, Kyowa Medex) was added. After a 1-h incubation and washing, substrate was added. Chemiluminescence was detected in a Multiskan MS (Labsystems Version 8.0, Helsinki, Finland). The sensitivity of MxA in this ELISA system was $3.2 \mathrm{ng} / \mathrm{mL}$.

Statistical analysis. All values are expressed as mean \pm SD. Subjects' demographic and clinical data between different groups were compared by the Kruskal-Wallis H test or the Mann-Whitney $U$ test, as appropriate. Receiver operating characteristic (ROC) analyses were conducted to evaluate the MxA level in screening for subjects with viral infection and to compare the performance with other two markers: WBC count and serum C-reactive protein (CRP) concentration (28). Ranges of these values were as follows; WBC: $0-32000 / \mathrm{mm}^{3}$, CRP: $0-4.2 \mathrm{mg} / \mathrm{dL}$, and MxA: $0-519.1 \mathrm{ng} / \mathrm{mL}(7.0$ $\mathrm{SD}$ ). Comparison of the area under ROC curves was done using the method of Hanley and McNeil (29). Statistical significance was defined as a $p<0.05$.

\section{RESULTS}

Age, male-to-female ratio, and duration of fever were similar in the febrile groups (Table 1). Influenza viruses, adenovirus, and rotavirus were the most common viruses in the etiologically diagnosed viral infection group. Upper respiratory infection accounted for most of the patients in the clinically diagnosed viral group, followed by gastroenterocolitis. In the bacterial infection group, urinary tract infection (UTI), pneumonia, and sepsis were the most common diseases, and Escherichia coli, Haemophilus influenzae, and Staphylococcus aureus were the most common pathogens.

Figure 1 shows peripheral whole blood MxA levels in all 


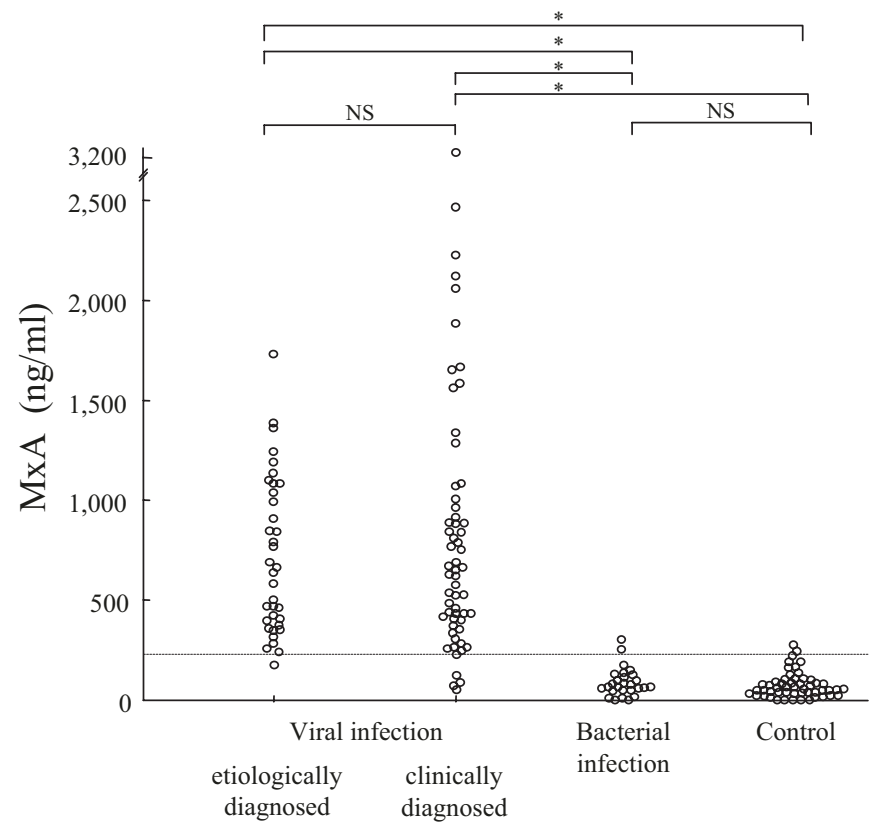

Figure 1. Whole blood MxA levels in children with acute onset fever measured by ELISA. Subjects were stratified according to the final diagnosis. Data points represent values from individual subjects. The horizontal dotted line represents the cutoff level for the upper limit of normal (mean $+2.5 \mathrm{SD}$ of the control subjects). ${ }^{*} p<0.01$; NS, not significant.

subjects. MxA levels in the control subjects were quite low, and the mean MxA levels in the control and bacterial infection group were similar $(76.9 \pm 63.2$ and $90.9 \pm 69.7 \mathrm{ng} / \mathrm{mL}$, respectively). MxA levels were high in the majority of the children with viral infections, in both the etiologically diagnosed and clinically diagnosed viral infection groups (719.2 \pm 386.4 and $827.0 \pm 651.1$, respectively). Although MxA levels were distributed in a wide range in the viral infection groups, no relationship between the MxA level and severity of illness was found. Using an MxA level of $234 \mathrm{ng} / \mathrm{mL}$ (mean \pm 2.5 $\mathrm{SD}$ of the control subjects) as the upper limit of normal, an elevated MxA level was $92.6 \%$ specific and had a positive likelihood ratio of 13.1 for viral infection. The peripheral WBC count and serum CRP concentration have been used as markers to distinguish bacterial from viral infection. Both values were higher in the bacterial infection group in the viral infection groups (Fig. 2). However, there were clear overlaps between the bacterial and viral infection groups for both values. ROC analysis was used to compare the effectiveness of WBC, CRP, and MxA in screening for viral infection among febrile children (Fig. 3). The area under the ROC curve of MxA level was $17.2 \%$ and $16.0 \%$ greater than the areas under the WBC count and CRP concentration curves, respectively $(p<0.01)$.

The 39 infants younger than 3 mo old were classified as "high risk" or "not high risk" for bacterial infection based on Bachur's criteria (26). The mean MxA level in the "not high risk" group was higher than in the "high risk" group $(p<0.01)$ (Fig. 4). Although most infants with viral infection were classified into the "not high risk" group, five infants with a normal MxA level ultimately were diagnosed with a bacterial infection: 2 cases of sepsis, 2 cases of UTI, and 1 case of pneumonia.
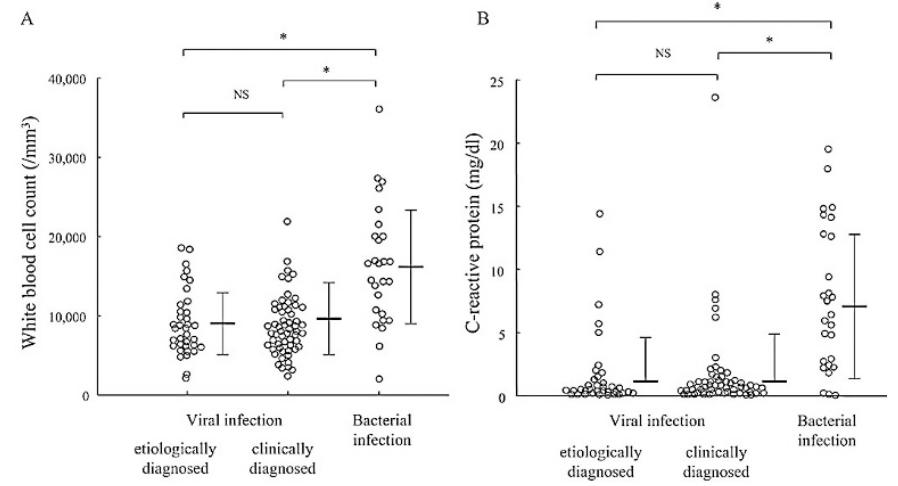

Figure 2. White blood cell counts $(A)$ and C-reactive protein concentrations $(B)$ in children with acute onset fever. These values were measured in samples obtained at the same time when samples were obtained for MxA protein assay. Thick horizontal bars indicate the average for each group, and error bars indicate the SD. ${ }^{*} p<0.001$, NS: not significant.

\section{DISCUSSION}

The present study shows that a whole blood assay for the MxA protein by ELISA is useful for identifying children whose fever is due to a viral infection. Our results are consistent with other reports, although the number of subjects studied has been small $(22,23)$. Forster et al. (21) measured MxA protein levels in blood and nasopharyngeal secretions in children with respiratory infections and obtained results similar to ours. However, these investigators only studied patients with respiratory symptoms.

The higher MxA levels in the viral infection group compared with the bacterial infection group can be explained by the fact that the MxA protein is induced exclusively by type I IFN and not by IFN-gamma, IL-1, TNF-alpha, or any of the other cyotokines by bacterial infection (15). Ronni et al. (16) demonstrated that MxA mRNA is detectable in isolated PBMC stimulated with IFN- $\alpha$ within 1 to $2 \mathrm{~h}$ of IFN induction, and MxA protein begins to accumulate shortly thereafter. Roers et al. (30) showed that MxA protein is induced in PBMC from healthy volunteers vaccinated with yellow fever virus 5-7 d after vaccination and remains detectable until approximately $10 \mathrm{~d}$ after vaccination. Once viral infection causes systemic symptoms like fever in its host, MxA protein should be detectable in PBMC.

One limitation of this study is that the diagnoses of viral infections were made by virus-detection kits, elevated serum

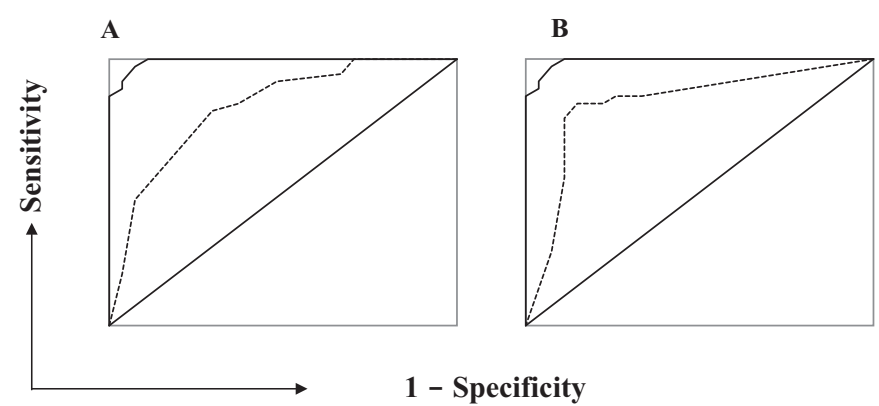

Figure 3. Area under the ROC curve for parameters for predicting viral infection. The area under the ROC curve of the MxA level (solid line) was compared with the WBC count $(A$, dotted line) and CRP concentration $(B$, dotted line). 


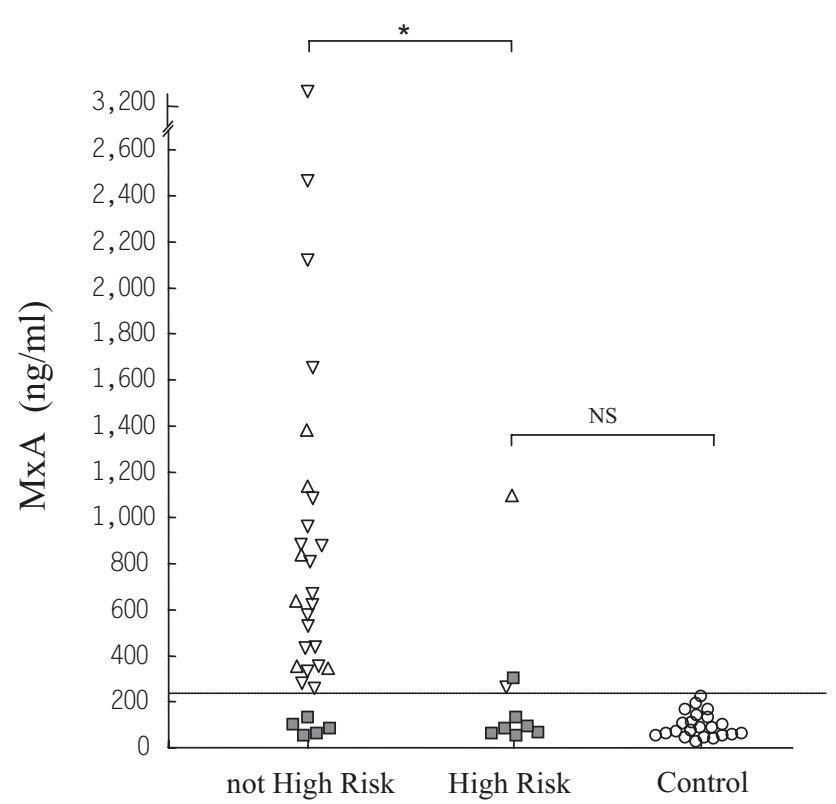

Figure 4. MxA levels of febrile infants younger than 3 mo old. According to Bachur's criteria for predicting bacterial infection, subjects were divided into "not high risk" $(n=30)$ or "high risk" $(n=9)$ groups. The three subject groups also are represented: etiologically diagnosed viral infection (open triangle), clinically diagnosed viral infection (open inverted triangle), and bacterial infection (closed square). The mean MxA levels were compared with controls $(n=22)$. Horizontal dotted line represents the cutoff for the upper limit of normal (mean $\pm 2.5 \mathrm{SD}$ of the control subjects). $* p<0.001$, NS: not significant.

antibody titers, and typical clinical findings, not by polymerase chain reaction (PCR). In the clinical setting, so many kinds of viruses cause fever in children that it is almost impossible to test for each one individually. Therefore, a nonspecific test, such as the whole blood MxA assay, is a useful screening tool. Although the possibility of coinfection or superinfection with another microorganism exists, we found no evidence of coinfection in this study. The low incidence of bacterial infection in febrile children with virus infection has previously been documented (31), whereas approximately $30 \%$ of children with Mycoplasma pneumoniae infection also have a viral infection (32). Suspected Mycoplasma pneumoniae or Chlamydia pneumoniae infection was an exclusion criterion in this study and may account for the low rate of coinfection. However, coinfection remains an important issue in the management of febrile children.

Recently, it has been reported that Gram-negative bacterial products, such as lipopolysaccharide (LPS), can induce type 1 IFN gene expression in mice $(33,34)$. Because MxA protein is induced exclusively by type 1 IFN $(14,15)$, we studied the effect of LPS on MxA protein induction in human PBMC. MxA protein was induced after a 24-h incubation with LPS (data not shown). However, the concentrations of LPS induced MxA protein were higher than $100 \mathrm{pg} / \mathrm{mL}$, and such high levels of endotoxin occur only in mostly fatal patients with sepsis caused by Gram-negative bacteria (35-37). Serum type 1 IFN levels remain within normal limits, even in patients with severe bacterial infection $(38,39)$, and normal type 1 IFN concentrations $(<10 \mathrm{U} / \mathrm{mL})$ lack the ability to induce the MxA protein in PBMC (data not shown). From these facts,
MxA protein is still a useful marker for viral infection in the clinical settings. However, in the management of critically ill patients, physicians should not make a final diagnosis of viral infection based on MxA titers alone, and should perform other diagnostic examinations as well.

In this study, supranormal peripheral MxA levels predicted a high likelihood (odds ratio, 13.6) for viral infection. ROC analyses demonstrated that the whole blood MxA level was more reliable for identifying viral infection than the WBC count or serum CRP concentrations. These data are consistent with other studies that have demonstrated the limitations of these variables for distinguishing between viral and bacterial infections (40-42). Most infants less than 3 mo of age classified correctly into the "not high risk" and "high risk" groups defined by Bachur's criteria. However, several infants in the "not high risk" group had a bacterial infection, and their MxA level was below the upper limit of normal. Combining MxA titers with other parameters could enhance the ability to distinguish between bacterial and viral infections in children with acute fever.

In conclusion, the whole blood assay for MxA protein may help identify which febrile children, even infants, have a viral infection, and might contribute to reduce the number of unnecessary antibiotic prescriptions. However, MxA alone is not pathonomonic for viral infection, and further studies are necessary to establish whether MxA-guided antibiotic use is safe and effective in the management of children with acute onset of fever.

Acknowledgments. The authors thank Dr Gyokei Murakami (Department of Pediatrics, Toyama Red Cross Hospital), Dr Masayoshi Miura (Department of Pediatrics, Toyama City Hospital), Dr Hiromichi Kubota (Department of Pediatrics, Kouseiren Takaoka Hospital) and Dr Yoichi Onoue (Department of Pediatrics, Toyama Prefectural Central Hospital) for their recruitment of the subjects. And they thank C Sakai and $\mathrm{H}$ Moriuchi for their excellent technical assistance.

\section{REFERENCES}

1. Makela MJ, Puhakka T, Ruuskanen O, Leinonen M, Saikku P, Kimpimaki M, Blomqvist S, Hyypia T, Arstila P 1998 Viruses and bacteria in the etiology of the common cold. J Clin Microbiol 36:539-542

2. Huang N, Morlock L, Lee CH, Chen LS, Chou YJ 2005 Antibiotic prescribing for children with nasopharyngitis (common colds), upper respiratory infections, and bronchitis who have health-professional parents. Pediatrics 116:826-832

3. Baker MD, Bell LM, Avner JR 1993 Outpatient management without antibiotics of fever in selected infants. N Engl J Med 329:1437-1441

4. Baskin MN, O'Rourke EJ, Fleisher GR 1992 Outpatient treatment of febrile infants 28 to 89 days of age with intramuscular administration of ceftriaxone. J Pediatr 120:22-27

5. Jaskiewicz JA, McCarthy CA, Richardson AC, White KC, Fisher DJ, Dagan R, Powell KR 1994 Febrile infants at low risk for serious bacterial infection-an appraisal of the Rochester criteria and implications for management. Febrile Infant Collaborative Study Group. Pediatrics 94:390-396

6. Le Bon A, Tough DF 2002 Links between innate and adaptive immunity via type I interferon. Curr Opin Immunol 14:432-436

7. Samuel CE 2001 Antiviral actions of interferons. Clin Microbiol Rev 14:778-809

8. Staeheli P, Pitossi F, Pavlovic J 1993 Mx proteins: GTPases with antiviral activity. Trends Cell Biol 3:268-272

9. van der Bliek AM 1999 Functional diversity in the dynamin family. Trends Cell Biol 9:96-102

10. Staeheli P, Haller O, Boll W, Lindenmann J, Weissmann C 1986 Mx protein: constitutive expression in $3 \mathrm{~T} 3$ cells transformed with cloned Mx cDNA confers selective resistance to influenza virus. Cell 44:147-158

11. Zhao H, De BP, Das T, Banerjee AK 1996 Inhibition of human parainfluenza virus-3 replication by interferon and human MxA. Virology 220:330-338

12. Schnorr JJ, Schneider-Schaulies S, Simon-Jodicke A, Pavlovic J, Horisberger MA, ter Meulen V 1993 MxA-dependent inhibition of measles virus glycoprotein synthesis in a stably transfected human monocytic cell line. J Virol 67:4760-4768 
13. Chieux V, Chehadeh W, Harvey J, Haller O, Wattre P, Hober D 2001 Inhibition of coxsackievirus B4 replication in stably transfected cells expressing human MxA protein. Virology 283:84-92

14. Ronni T, Matikainen S, Sareneva T, Melen K, Pirhonen J, Keskinen P, Julkunen I 1997 Regulation of IFN- $\alpha$ /beta, MxA, 2',5'-oligoadenylate synthetase, and HLA gene expression in influenza A-infected human lung epithelial cells. J Immunol 158:2363-2374

15. Simon A, Fah J, Haller O, Staeheli P 1991 Interferon-regulated Mx genes are not responsive to interleukin-1, tumor necrosis factor, and other cytokines. J Virol 65:968-971

16. Ronni T, Melen K, Malygin A, Julkunen I 1993 Control of IFN-inducible MxA gene expression in human cells. J Immunol 150:1715-1726

17. Meier V, Mihm S, Ramadori G 2000 MxA gene expression in peripheral blood mononuclear cells from patients infected chronically with hepatitis $\mathrm{C}$ virus treated with interferon-alpha. J Med Virol 62:318-326

18. Deisenhammer F, Reindl M, Harvey J, Gasse T, Dilitz E, Berger T 1999 Bioavailability of interferon beta $1 \mathrm{~b}$ in MS patients with and without neutralizing antibodies. Neurology 52:1239-1243

19. Itazawa T, Adachi Y, Imamura H, Okabe Y, Yamamoto J, Onoue Y, Adachi YS, Miyawaki T, Murakami G 2001 Increased lymphoid MxA expression in acute asthma exacerbation in children. Allergy 56:895-898

20. Itazawa T, Adachi Y, Nakabayashi M, Fuchizawa T, Murakami G, Miyawaki T 2006 Theophylline metabolism in acute asthma with MxA-indicated viral infection. Pediatr Int 48:54-57

21. Forster J, Schweizer M, Schumacher RF, Kaufmehl K, Lob S 1996 MxA protein in infants and children with respiratory tract infection. Acta Paediatr 85:163-167

22. Halminen M, Ilonen J, Julkunen I, Ruuskanen O, Simell O, Makela MJ 1997 Expression of MxA protein in blood lymphocytes discriminates between viral and bacterial infections in febrile children. Pediatr Res 41:647-650

23. Chieux V, Hober D, Harvey J, Lion G, Lucidarme D, Forzy G, Duhamel M, Cousin J, Ducoulombier H, Wattre P 1998 The MxA protein levels in whole blood lysates of patients with various viral infections. J Virol Methods 70:183-191

24. Chieux V, Hober D, Chehadeh W, Harvey J, Alm G, Cousin J, Ducoulombier H, Wattre P 1999 MxA protein in capillary blood of children with viral infections. J Med Virol 59:547-551

25. Esposito S, Blasi F, Arosio C, Fioravanti L, Fagetti L, Droghetti R, Tarsia P, Allegra L, Principi N 2000 Importance of acute Mycoplasma pneumoniae and Chlamydia pneumoniae infections in children with wheezing. Eur Respir J 16:1142-1146

26. Bachur RG, Harper MB 2001 Predictive model for serious bacterial infections among infants younger than 3 months of age. Pediatrics 108:311-316

27. Towbin H, Schmitz A, Jakschies D, Von Wussow P, Horisberger MA 1992 A whole blood immunoassay for the interferon-inducible human Mx protein. J Interferon Res 12:67-74

28. Hanley JA, McNeil BJ 1982 The meaning and use of the area under a receiver operating characteristic (ROC) curve. Radiology 143:29-36
29. Hanley JA, McNeil BJ 1983 A method of comparing the areas under receiver operating characteristic curves derived from the same cases. Radiology 148:839843

30. Roers A, Hochkeppel HK, Horisberger MA, Hovanessian A, Haller O 1994 MxA gene expression after live virus vaccination: a sensitive marker for endogenous type I interferon. J Infect Dis 169:807-813

31. Greenes DS, Harper MB 1999 Low risk of bacteremia in febrile children with recognizable viral syndromes. Pediatr Infect Dis J 18:258-261

32. Heiskanen-Kosma T, Korppi M, Jokinen C, Kurki S, Heiskanen L, Juvonen H, Kallinen S, Sten M, Tarkiainen A, Ronnberg PR, Kleemola M, Makela PH, Leinonen M 1998 Etiology of childhood pneumonia: serologic results of a prospective, population-based study. Pediatr Infect Dis J 17:986-991

33. Sakaguchi S, Negishi H, Asagiri M, Nakajima C, Mizutani T, Takaoka A, Honda K, Taniguchi T 2003 Essential role of IRF-3 in lipopolysaccharide-induced interferonbeta gene expression and endotoxin shock. Biochem Biophys Res Commun 306:860-866

34. O'Connell RM, Saha SK, Vaidya SA, Bruhn KW, Miranda GA, Zarnegar B, Perry AK, Nguyen BO, Lane TF, Taniguchi T, Miller JF, Cheng G 2004 Type I interferon production enhances susceptibility to Listeria monocytogenes infection. J Exp Med 200:437-445

35. Venet C, Zeni F, Viallon A, Ross A, Pain P, Gery P, Page D, Vermesch R, Bertrand M, Rancon F, Bertrand JC 2000 Endotoxaemia in patients with severe sepsis or septic shock. Intensive Care Med 26:538-544

36. Cohen J 2000 The detection and interpretation of endotoxaemia. Intensive Care Med 26:S51-S56

37. Marshall JC, Walker PM, Foster DM, Harris D, Ribeiro M, Paice J, Romaschin AD, Derzko AN 2002 Measurement of endotoxin activity in critically ill patients using whole blood neutrophil dependent chemiluminescence. Crit Care 6:342-348

38. Girardin E, Grau GE, Dayer JM, Roux-Lombard P, Lambert PH 1988 Tumor necrosis factor and interleukin-1 in the serum of children with severe infectious purpura. N Engl J Med 319:397-400

39. Calandra T, Baumgartner JD, Grau GE, Wu MM, Lambert PH, Schellekens J, Verhoef J, Glauser MP 1990 Prognostic values of tumor necrosis factor/cachectin, interleukin-1, interferon-alpha, and interferon-gamma in the serum of patients with septic shock. Swiss-Dutch J5 Immunoglobulin Study Group. J Infect Dis 161:982-987

40. Korppi M, Heiskanen-Kosma T, Leinonen M 1997 White blood cells, C-reactive protein and erythrocyte sedimentation rate in pneumococcal pneumonia in children. Eur Respir J 10:1125-1129

41. Heiskanen-Kosma T, Korppi M 2000 Serum C-reactive protein cannot differentiate bacterial and viral aetiology of community-acquired pneumonia in children in primary healthcare settings. Scand J Infect Dis 32:399-402

42. Virkki R, Juven T, Rikalainen H, Svedstrom E, Mertsola J, Ruuskanen O 2002 Differentiation of bacterial and viral pneumonia in children. Thorax 57:438-441 